\title{
BUT WHAT ABOUT TEXAS? CLIMATE DISRUPTION REGULATION IN RECALCITRANT STATES
}

\author{
Thomas O. McGarity*
}

Introduction ....................................... $\quad 79$

I. Implementing EPA's Greenhouse Gas Regulations ............ 80

A. EPA's GHG Regulations .......................... 81

B. States Begin to Implement the Rules ............... 81

C. EPA Takes Over Texas's Permitting Authority ........... 82

D. Dual Permitting of Texas's Coal-Fired Power Plants ....... 83

E. Armendariz Resigns............................. 84

F. EPA Backs Off as It Attempts to Resume Control .......... 84

II. The Supreme Court Decides UARG .................... 87

III. The Impact of UARG on GHG Regulation in Texas ........... 88

Conclusion ........................................ $\quad 90$

\section{INTRODUCTION}

The State of Texas has had a long history of resistance to federal environmental regulation. ${ }^{1}$ For most of the past forty years, Texas's political leadership has been far more concerned about the negative impact that environmental regulation could have on economic growth than with the effects that pollutants could have on human beings and the global environment. ${ }^{2}$ The state's environmental protection agency, the Texas Commission on Environmental Quality ("TCEQ"), has historically taken the position that its highly qualified staff is capable of achieving the Clean Air Act's environmental goals with little oversight from the U.S. Environmental Protection Agency ("EPA"). ${ }^{3}$ The state's powerful congressional delegation has often persuaded EPA to look the other way when TCEQ failed to meet the state's obligations under federal law. ${ }^{4}$ Despite frequent complaints from environmental groups that TCEQ was a "toothless lapdog" for the industries that it was supposed to be regulating, ${ }^{5}$ EPA has historically handled Texas with kid gloves. ${ }^{6}$

That changed rather dramatically during the Obama Administration when a committed EPA Regional Administrator assumed permitting responsibilities

\footnotetext{
* Joe R. and Teresa Lozano Long Endowed Chair in Administrative Law, University of Texas School of Law.

${ }^{1}$ See generally Neela Banerjee, In Climate Politics, Texas Aims to Be the Anti-California, L.A. Times (Nov. 7, 2010), http://perma.cc/7ERU-8KM5.

${ }^{2}$ See id.

${ }^{3}$ See Gabriel Nelson, By Messing With Texas Air Pollution Permits, EPA Unleashes Power Struggle, Greenwire, Aug. 10, 2010 (quoting Bill Becker, Executive Director, National Association of Clean Air Agencies).

${ }^{4}$ Banerjee, supra note 1 (quoting Tom Smith, Texas State Director, Public Citizen).

${ }^{5}$ Matthew Tresaugue, Environmental Watchdog Urged to Respond Better to Public, Hous. Chron. (Nov. 19, 2010), http://perma.cc/5CDN-GB73.

${ }^{6}$ See Katherine Gregor, Environmental Cage Match: After a History of Pulling Its Punches, is the EPA Finally Forcing TCEQ to Clean up the Texas Air?, Austin Chron. (May 28, 2010), http://per ma.cc/8AZP-7GS4.
} 
for the greenhouse gas ("GHG") emissions of major stationary sources in Texas after TCEQ's Chairman and the Attorney General of Texas informed EPA that Texas would have no part of a program that they believed to be wholly unlawful and illegitimate. At the same time that Texas refused to implement EPA's GHG regulations, it vigorously challenged them in the D.C. Circuit Court of Appeals. Texas ultimately lost all of those appeals, the most recent of which was the Supreme Court's decision in Utility Air Regulatory Group v. $E P A$ (“UARG"). ${ }^{7}$ But by no means is Texas resigned to following EPA's lead in regulating GHG emissions to avoid climate disruption.

This Essay will recount the history of EPA's efforts to deal with a recalcitrant state bureaucracy and EPA-bashing political leaders as EPA attempted to reduce GHG emissions in a state that emitted more GHGs than any other state. ${ }^{8}$ It will then offer some observations on the impact of $U A R G$ on the future of GHG regulation in Texas, a state that views $U A R G$ as a victory and remains adamantly opposed to regulating GHGs unless required to do so by federal law.

\section{Implementing EPA’s Greenhouse Gas Regulations}

When several states challenged EPA's denial of their petition to regulate GHG emissions from automobiles in Massachusetts v. EPA, ${ }^{9}$ Texas was not among them. It intervened as a defendant to argue that EPA had no business regulating GHGs. ${ }^{10}$ Although TCEQ is the second-largest environmental protection agency in the world with 3,000 employees and a $\$ 466$ million budget, ${ }^{11}$ it has earned a reputation as an industry-friendly regulator that would bend over backwards to avoid imposing costly controls on Texas businesses. ${ }^{12}$ In late 2009, Governor Rick Perry appointed Bryan W. Shaw, a professor of engineering at Texas A\&M University who was deeply skeptical of claims that GHG emissions caused climate disruption, to be TCEQ's Chairman..$^{13}$ The Texas Legislature, meanwhile, was dominated by free market advocates who were committed to doing the minimum necessary to allow TCEQ to satisfy the federal Clean Air Act's requirements. ${ }^{14}$ According to a former TCEQ Commissioner,

\footnotetext{
${ }^{7} 134$ S. Ct. 2427 (2014).

${ }^{8}$ Neena Satija, Texas, Leader in Greenhouse Gases, Stands Vulnerable to Their Effects, N.Y. Times (July 12, 2014), http://perma.cc/73UE-YQNL.

9549 U.S. 497 (2007).

${ }^{10}$ See id. at 505.

${ }^{11}$ Asher Price, A Soft Touch up for Review, Austin Am.-Statesman, Nov. 7, 2010, at A1.

${ }^{12}$ See, e.g., Asher Price, Attorney Helped Set Rules on Pollution, Austin Am.-Statesman, Nov. 8,2010 , at A1 (describing private meetings between Commissioner and regulated entity while company was seeking permit).

${ }^{13}$ See Susanne Pagano, Environmental Group Sues State Regulators to Force Regulation of Greenhouse Emissions, 40 Env't Rep. (BNA) 2376 (Oct. 9, 2009); Gov. Perry Appoints Shaw to Texas Commission on Environmental Quality, OfF. OF tHe Governor Rick Perry (Nov. 1, 2007), http://perma.cc/SVR6-P3V8.

${ }^{14}$ R.G. Ratcliffe, Environmentalists May Have Upper Hand over Top Polluters, Hous. Chron. (June 7, 2010), http://perma.cc/D7M2-WC3E.
} 
there was "a culture at the agency and in the state that economic interests are more protected ... than the environment." 15

Having lost Massachusetts v. EPA, ${ }^{16}$ TCEQ and the state political leadership remained adamant in their opposition to regulating GHGs. ${ }^{17}$ Governor Rick Perry predicted that limits on GHG emissions would wreck the state's economy and raise electricity rates for everyone. ${ }^{18}$ Claiming that the science on global warming was "far from settled," Chairman Shaw declared that "[r]educing [carbon dioxide] in Texas will do nothing to lower [carbon dioxide] globally, but will have the effect of sending U.S. jobs to China and India." 19

\section{A. EPA's GHG Regulations}

President Obama's first EPA Administrator, Lisa Jackson, was far more inclined than her immediate Bush Administration predecessors to force states to toe the line in implementing the Clean Air Act. Jackson chose Al Armendariz, an environmental and civil engineering professor at Southern Methodist University, to head EPA's Region VI office, which was responsible for Texas and two other states..$^{20}$ An outspoken critic of TCEQ, Armendariz had worked as a consultant to state and local environmental groups in air pollution disputes. ${ }^{21}$ One of his most important responsibilities was to oversee the implementation of EPA's GHG regulations in Texas during the time that Texas was challenging the rules in the $U A R G$ litigation. ${ }^{22}$

\section{B. States Begin to Implement the Rules}

Following EPA's Timing and Tailoring Rules, nearly eighty percent of the states were committed to putting GHG permitting programs into effect by the January 2, 2011 deadline. ${ }^{23}$ Even states that challenged the rules in court were trying to put programs into effect so that they could administer the federal program if it survived judicial review. A total of thirteen states lacked authority to administer GHG permitting programs, but seven of those were confident that they could obtain that authority by the deadline. ${ }^{24}$ Six others agreed to accept a

\footnotetext{
${ }^{15} I d$. (quoting Larry Soward, former Commissioner, TCEQ).

${ }^{16}$ See 549 U.S. 497, 534-35 (2007).

${ }^{17}$ Banerjee, supra note 1.

${ }^{18}$ Asher Price, Perry Says Carbon Dioxide Limits Would Destroy State's Economy, Austin Am.Statesman, June 10, 2009, at B5.

${ }^{19}$ Pagano, supra note 13.

${ }^{20}$ Matthew Tresaugue, SMU Professor Will Be Texas' Next EPA Chief, Hous. Chron. (Nov. 5, 2009), http://perma.cc/T9BE-4A3Y.

${ }^{21}$ See id.

${ }^{22}$ See Gabriel Nelson, Texas Joins Challengers to EPA's Greenhouse Gas 'Tailoring' Rule, GreENWIRE, Aug. 5, 2010.

${ }^{23}$ Vincent Valk \& Kara Sissell, Officials Say Most States on Schedule for GHG Permitting, CHEMICAL WK., Sept. 20, 2010, at 12.

${ }^{24}$ State Air Agencies See "Seamless" Movement to Greenhouse Gas Permits as 2011 Begins, Elec. Util. WK., Nov. 1, 2010, at 3.
} 
Federal Implementation Plan ("FIP") that EPA was in the process of preparing. ${ }^{25}$ Only Texas refused to revise its permit program or accept the FIP. ${ }^{26}$

On August 2, TCEQ Chairman Bryan Shaw and Texas Attorney General Greg Abbott wrote a defiant six-page letter to EPA stating, "Texas has neither the authority, nor the intention of interpreting, ignoring, or amending its laws in order to compel the permitting of greenhouse gas emissions." ${ }^{27}$ Carbon dioxide was, in their opinion, "a uniformly distributed, trace constituent of clean air, vital to all life, that [was] emitted by all productive activities on Earth." 28 Shaw later explained that he saw no "value in pursuing what is sort of a farce that is going to have only cost and no environmental benefits." 29

In his response to the August 2 letter, Armendariz maintained that EPA's GHG regulations were "measured steps" in response to the Supreme Court's opinion in Massachusetts v. EPA..$^{30} \mathrm{He}$ dismissed the letter's "unsubstantiated claims" as the sort of arguments that "have been made_and ultimately proven wrong-every time EPA has, over the past forty years, moved to implement the Clean Air Act's protections of public health and welfare." ${ }^{31}$ Behind the scenes, Armendariz reached out to companies with large industrial facilities in Texas to urge them to convince the TCEQ Commissioners to cooperate with EPA. ${ }^{32}$

\section{EPA Takes Over Texas's Permitting Authority}

On December 23, 2010, Administrator Jackson signed an interim final rule "correcting" its 1992 approval of the Texas State Implementation Plan ("SIP"), changing the approval to a partial approval and partial disapproval, and promulgating a FIP establishing a permitting program for GHG-emitting sources in Texas. ${ }^{33}$ The preamble stated that recent statements by Texas made it "particularly evident" that when EPA approved the major revisions to the Texas SIP implementing the 1990 Clean Air Act Amendments, the SIP still had

\footnotetext{
${ }^{25} I d$. The Clean Air Act requires states to submit for EPA approval State Implementation Plans ("SIPs") containing regulations and permit requirements that are requisite to attaining the National Ambient Air Quality Standards ("NAAQS") by various statutory deadlines. 42 U.S.C. $\S 7410(a)(2)$ (2012). If a state fails to submit an adequate SIP, EPA must prepare a Federal Implementation Plan for the state. Id. § 7410(c).

${ }^{26}$ State Air Agencies See "Seamless" Movement to Greenhouse Gas Permits as 2011 Begins, supra note 24 , at 3.

${ }^{27}$ Letter from Bryan W. Shaw, Chairman, Tex. Comm'n on Envtl. Quality, and Greg Abbott, Attorney Gen. of Tex., to Lisa Jackson, Adm'r, EPA, and Alfredo Armendariz, Reg'l Adm'r, EPA Region 6 (Aug. 2, 2010), http://perma.cc/QQW4-DN3M.

${ }^{28}$ Id. at 2.

${ }^{29}$ Robin Bravender, EPA Push on Emission Regs Sparks State Permitting Scrambles, Fury, GreEnwire, Aug. 18, 2010.

${ }^{30} \mathrm{Id}$.

${ }^{31}$ Steven D. Cook, Texas Informs EPA of Refusal to Implement Requirements for Greenhouse Gas Permits, 41 Env't Rep. (BNA) 1751 (Aug. 6, 2010).

${ }^{32}$ EPA Seeks Industry Help Pushing Texas to Drop Fight over GHG Permits, Clean Air ReP., Sept. 30, 2010.

${ }_{33}^{33}$ Determinations Concerning Need for Error Correction, Partial Approval and Partial Disapproval, and Federal Implementation Plan Regarding Texas Prevention of Significant Deterioration Program, 75 Fed. Reg. 82,430, 82,430 (Dec. 30, 2010).
} 
a significant gap in coverage - it had failed to address pollutants newly subject to regulation as required by the Clean Air Act. ${ }^{34}$ The SIP was flawed at the time, and EPA had not addressed those flaws..$^{35}$ The Agency was now correcting its previous error by partially disapproving the relevant portions of the SIP. ${ }^{36}$ Since more than two years had passed since EPA should have disapproved the Texas SIP, it "exercis[ed] its discretion to immediately promulgate" a FIP under which EPA assumed GHG permitting responsibilities. ${ }^{37}$ While TCEQ remained responsible for permitting emissions of the conventional pollutants, the FIP applied EPA's regulatory program to the GHG portion of any permit issued after January 2, 2011. ${ }^{38}$ Although TCEQ characterized the takeover as "an arrogant act by an overreaching EPA," 39 the D.C. Circuit rejected Texas's challenge to the action. ${ }^{40}$

\section{Dual Permitting of Texas's Coal-Fired Power Plants}

While Governor Perry and Chairman Shaw were castigating EPA in the press and challenging its takeover of the GHG permitting process in the courts, companies with GHG emissions that crossed the Tailoring Rule's thresholds were quietly applying for and receiving GHG permits from EPA's Region VI. ${ }^{41}$ Region VI issued the first GHG permit, for a 540-megawatt unit at the Lower Colorado River Authority's Thomas C. Ferguson plant near Marble Falls, Texas, ${ }^{42}$ only eight months after it received the application, thereby defying industry predictions that EPA would unduly delay the permitting process. ${ }^{43}$ Not all proceedings, however, went so smoothly. For example, Chase Power Development's massive Las Brisas Energy Center project, which was designed to burn an unwanted byproduct of petroleum refineries called petroleum coke or "petcoke," received a Prevention of Significant Deterioration ("PSD") permit from TCEQ, but the company cancelled the project after it failed to persuade

\footnotetext{
${ }^{34} I d$. at 82,431; see 42 U.S.C. § 7475(a)(1) (2012).

${ }^{35}$ Determinations Concerning Need for Error Correction, Partial Approval and Partial Disapproval, and Federal Implementation Plan Regarding Texas Prevention of Significant Deterioration Program, 75 Fed. Reg. at 82,433.

${ }^{36} I d$. To the author's knowledge, EPA's decision to "correct" a SIP approval after almost two decades was unprecedented.

${ }^{37} \mathrm{Id}$.

${ }^{38} I d$.

${ }^{39}$ Housley Carr, Environmental Protection Agency Takes over GHG Authority in Texas from State Agency, Global Power ReP., Dec. 23, 2010.

${ }^{40}$ Texas v. EPA, 726 F.3d 180, 200 (D.C. Cir. 2013).

${ }^{41}$ Patrick Michels, Toxic Avenger: In the War Between the Feds and Texas, EPA Chief Al Armendariz Has Science on His Side. Is That Enough?, Dallas ObServer (Mar. 10, 2011), http:/ /perma.cc/8LZB-AX6B.

${ }^{42}$ Wijdan Khaliq, LCRA Selects GE Technology for Planned 540-MW Texas Replacement Project, SNL ENERGy FIN. DaILY, Mar. 14, 2012.

${ }^{43}$ See Matthew Tresaugue, EPA Gives Permit as Texas Refuses, Hous. Chron., Nov. 11, 2011, at B1.
} 
EPA to exempt it from the Tailoring Rule and the proposed New Source Performance Standard for fossil fuel-fired power plants. ${ }^{44}$

\section{E. Armendariz Resigns}

On April 25, 2012, Senator James Inhofe (R-Oklahoma) released a video of a speech in which Regional Administrator Armendariz described his philosophy of enforcement. ${ }^{45} \mathrm{He}$ related how the Romans conquered small villages by crucifying "the first five guys they saw." 46 The point was to "[f]ind people who are not compliant with the law, and you hit them as hard as you can and you make examples out of them, and there is a great deterrent effect there." ${ }^{47}$ Fox News and conservative commentators seized on the video to criticize the Obama Administration's "radical eco-bureaucrats." 48 Although Armendariz quickly apologized for his "offensive and inaccurate" remarks, ${ }^{49}$ his apologies did not satisfy Senator Inhofe and the other critics who maintained that Armendariz was accurately relating EPA's enforcement policy. ${ }^{50}$ Five days after Inhofe publicized the video, Armendariz resigned. ${ }^{51}$ In a demonstration that the revolving door opens to public interest groups as well as industry, the Sierra Club hired Armendariz two months later to work on its "Beyond Coal" campaign. ${ }^{52}$

\section{F. EPA Backs Off as It Attempts to Resume Control}

In September 2012, Administrator Jackson appointed Ron Curry, a former head of the New Mexico Environment Department, to replace Armendariz as Regional Administrator. ${ }^{53}$ A TCEQ spokesperson hoped that the appointment would lead to "constructive dialogue with a refocus on sound science, the law

\footnotetext{
${ }^{44}$ See Susanne Pagano, Las Brisas Power Plant Developer Plans To Liquidate Assets, Suspend Texas Project, 44 Env't Rep. (BNA) 273 (Feb. 1, 2013); Texas Coke Plant May Be Key Test for EPA Takeover of State GHG Permit, Clean Energy ReP., Nov. 28, 2011.

45158 Cong. REC. 2676 (2012).

${ }^{46} I d$.

${ }^{47} \mathrm{Id}$.

${ }^{48}$ Erica Martinson, How Old 'Crucify' Video is New News, Politico (May 3, 2012), http://perma .cc/65K4-ZX5L (noting that the Armendariz video "spread like wildfire, leading the Drudge Report and getting airplay on Fox News"); Obama EPA Official Vows to "Crucify" Oil and Gas Industry, Rush LimbaugH Show (Apr. 26, 2012), http://perma.cc/6UTW-7CX3; Michelle Malkin, "Crucify Them": The Obama Way, Creators.com (Apr. 26, 2012), http://perma.cc/NL5G7MYQ.

${ }^{49}$ John M. Broder, E.P.A. Official Spoke of 'Crucifying' Polluters, N.Y. Times Green Blog (Apr. 26, 2012), http://perma.cc/FNU2-NG33.

50 Andrew Restuccia \& Ben German, GOP Pounces on EPA Official's Remarks About Crucifying Lawbreakers, THE HILl (Apr. 26, 2012), http://perma.cc/L9ER-8AD4.

${ }^{51}$ John M. Broder, EPA Official in Texas Quits over 'Crucify' Video, N.Y. Times (May 1, 2012), http://perma.cc/2D6G-Q3N7.

52 Jessica Coomes, Former EPA Regional Administrator to Join Sierra Club Beyond Coal Campaign, 43 Env't Rep. (BNA) 1756 (July 6, 2012).

${ }_{53}$ Nancy J. Moore, Selection of Region 6 Administrator Praised by Sierra Club, Rapped by Inhofe, 43 Env't Rep. (BNA) 2490 (Sept. 28, 2012).
} 
and historic interpretation of Texas programs at EPA." ${ }^{54}$ By early 2013, it was clear that Region VI was in full retreat. ${ }^{55}$ Over the next year and a half, it finalized forty-one GHG permits for projects in Texas and proposed another ten for approval. ${ }^{56}$ Some of these permits were approved over the vigorous opposition of environmental groups. ${ }^{57}$

In June 2013, Governor Perry signed legislation empowering TCEQ to issue permits to major sources and major modifications of existing major sources of GHG emissions. ${ }^{58}$ The regulations that TCEQ proposed in order to implement the statute appeared for the most part to comply with EPA's requirements for state GHG permitting programs, but there were some controversial provisions as well..$^{59}$ As required by the Texas statute, the regulations provided that GHG permit applications would not be subject to adjudicatory "contested case" hearings, even though other permit applications were subject to such hearings. ${ }^{60}$ Instead, a challenger would be able to submit written comments and secure judicial review of a challenged permit in state district court. ${ }^{61}$ The regulations further provided that the permitting officials would not consider the incremental impacts of the source's GHG emissions on global warming. ${ }^{62}$ Finally, they stated that Best Available Control Technology ("BACT") for GHGs would generally rely on fuel limitations and process controls aimed at increasing efficiency, but TCEQ would not consider "add on" controls like carbon capture and sequestration. ${ }^{63}$

Environmental groups objected to the provision that prevented a GHG permit application from becoming a "contested case," in which they would be allowed to present evidence and to cross-examine witnesses. ${ }^{64}$ They were especially concerned, however, about how TCEQ would administer case-by-case BACT determinations. ${ }^{65}$ Instead of the "top down" approach that EPA suggested for BACT determinations, TCEQ employed a "three-tier" approach under which a source's emissions-reduction proposal qualified as BACT under a "tier 1" analysis if it achieved performance levels equivalent to those of re-

\footnotetext{
${ }^{54} I d$.

${ }^{55}$ EPA Urged to Ramp up Scrutiny of Texas 'Minor' Source Air Permit Rules, Clean AiR ReP., Jan. 30, 2014.

${ }^{56}$ Christine Cordner, EPA Issues Final Air Permit for Texas Peaker Amid Movement on Pending Applications, SNL Generation Markets WK., June 10, 2014.

${ }^{57}$ See, e.g., In re La Paloma Energy Ctr., LLC, 2014 WL 1066556, at *12 (Mar. 14, 2014) (EPA Environmental Appeals Board order denying review of PSD appeal No. 13-10, PSD Permit No. TX-1288-GHG).

${ }^{58}$ H.B. 788, 2013 Leg., 83rd Sess. (Tex. 2013).

${ }^{59}$ TCEQ Releases Draft Rules for Taking over Texas Greenhouse Gas Permitting from EPA Region 6, BeVERIDGe \& Diamond (Oct. 21, 2013), http://perma.cc/28XG-5PSP.

${ }^{60}$ Tim Wilkins, Texas Regulators Take First Steps to Acquire Greenhouse Gas Permitting Authority, NAT'L L. ReV. (Oct. 10, 2013), http://perma.cc/QQA5-LSVS.

${ }^{61} I d$.

${ }^{62} \mathrm{Id}$.

${ }^{63} \mathrm{Id}$.

${ }^{64}$ Housley Carr, Generation Permits in Texas May Come Quicker, Platts Megawatt Daily, Jan. 6, 2014 (quoting Adrian Shelley, Executive Director, Air Alliance Houston).

${ }^{65}$ Texas Bid to Regain GHG Permit Power from EPA May Revive BACT Fight, ENERGyWashINGTON WK., Oct. 23, 2013.
} 
cently permitted sources in the same industry. ${ }^{66}$ If the proposal employed a novel technology, it had to undergo additional "tier 2" and sometimes "tier 3" analysis. ${ }^{67}$ Although EPA had previously approved TCEQ's three-tier approach for addressing conventional pollutants, several environmental groups had petitioned EPA in 2008 to prevent TCEQ from using that approach because it consistently allowed sources to employ less stringent technologies than EPA's approach. ${ }^{68}$ The petition argued that by focusing exclusively on technologies already in place, the TCEQ approach did not envision technological improvement over the years and therefore did not operate on a "case-by-case basis" as required by the Clean Air Act. ${ }^{69}$

To speed up the process of approving the changes to the Texas SIP that were necessary to allow TCEQ to assume responsibility for GHG permitting, EPA took the unusual step of engaging in "parallel processing," an approach to SIP approval that allowed the EPA staff to begin its analysis of the SIP revision while TCEQ was still allowing public comment on its proposal and reacting to those comments. ${ }^{70}$ The problem with parallel processing was the implicit assumption that the state would not change the proposal in any significant fashion in light of the public comments.

The assumption proved accurate, as the final regulations that TCEQ sent to EPA for approval did not vary significantly from the proposal..$^{71} \mathrm{By}$ the time TCEQ published them, EPA had already published a notice in the Federal Register proposing to approve most aspects of the regulations and proposing to rescind most aspects of the GHG FIP..$^{72}$ The preamble to the proposal provided EPA's analysis of the SIP revisions and stated its conclusion that TCEQ had sufficient authority "to apply the Texas PSD program to all pollutants newly subject to regulation, including non-NAAQS pollutants into the future."73 Despite the fact that it had not received public comment on the proposal, EPA then sent letters to all of the companies with pending permit applications for GHG permits giving them the option of completing the permit process with EPA or transferring them to TCEQ. ${ }^{74}$ On November 10, 2014, EPA formally approved TCEQ's revisions and withdrew the FIP. ${ }^{75}$

\footnotetext{
${ }^{66} \mathrm{Id}$.

${ }^{67} \mathrm{Id}$.

${ }^{68} \mathrm{Id}$.

${ }^{69} \mathrm{Id}$.
}

${ }^{70}$ See generally Approval and Promulgation of Air Quality Implementation Plans; Withdrawal of Federal Implementation Plan; Texas; Prevention of Significant Deterioration; Greenhouse Gas Tailoring Rule Revisions, 79 Fed. Reg. 9123 (Feb. 18, 2014).

${ }^{71}$ See generally Tex. Comm'n on Envtl. Quality, Chapter 122 - Federal Operating Permits Program, Rule Project Number 2013-040-116-A1, http://perma.cc/Y8VL-6L7E; Sandra Snyder \& Richard Alonso, Texas One Step Closer to Obtaining Authority to Issue GHG (Greenhouse Gas) Air Permits, Nat’L L. Rev., Mar. 31, 2014.

${ }^{72}$ Approval and Promulgation of Air Quality Implementation Plans; Withdrawal of Federal Implementation Plan; Texas; Prevention of Significant Deterioration; Greenhouse Gas Tailoring Rule Revisions, 79 Fed. Reg. at 9123.

${ }_{73}^{7}$ Id. at 9,131 .

${ }^{74}$ Snyder \& Alonso, supra note 71.

${ }^{75}$ Approval and Promulgation of Air Quality Implementation Plans; Texas; Prevention of Significant Deterioration; Greenhouse Gas Tailoring Rule Revisions, 79 Fed. Reg. 66,626 (Nov. 10, 
The fact that TCEQ was attempting to regain permitting authority over GHG emissions did not, however, mean that its leadership was any more convinced that GHG emissions posed a serious environmental risk. Indeed, a few days after the Intergovernmental Panel on Climate Change issued a major report concluding that "[w]arming of the climate system is unequivocal" and that the "largest contribution" to the warming is anthropogenic emissions of carbon dioxide, ${ }^{76}$ TCEQ Chairman Shaw told attendees of the Texas Tribune Festival that he was not satisfied that human beings contributed to global warming. ${ }^{77}$

\section{The Supreme Court Decides $U A R G$}

On June 23, 2014, the Supreme Court in UARG upheld the Timing and Tailoring Rules in part and reversed them in part. ${ }^{78}$ The Court first held that EPA had impermissibly interpreted the Clean Air Act to conclude that a source would have to undergo PSD New Source Review ("NSR") and obtain a Title V permit solely on the basis of its potential to emit GHGs. ${ }^{79}$ Although the Court in Massachusetts v. EPA had held that GHGs were "air pollutants" under the statute's broad definition of that term, the pollutants that triggered the PSD and Title $\mathrm{V}$ permit requirements were in a smaller category of regulated air pollutants. ${ }^{80}$ The Agency's Tailoring Rule did not make its interpretation of "air pollutant" in the NSR and Title V contexts any less unreasonable, because an agency had "no power to 'tailor' legislation to bureaucratic policy goals by rewriting unambiguous statutory terms." ${ }^{81}$ The Court noted that it would be "hard to imagine a statutory term less ambiguous than the precise numerical thresholds at which the Act requires PSD and Title V permitting." ${ }^{2}$

Turning its attention to sources that crossed the statutory thresholds for conventional pollutants (the so-called "anyway" sources), the Court held that EPA had reasonably interpreted the Act to require permit applicants to include GHGs in determining BACT requirements for those sources. ${ }^{83}$ The Court rejected the industry argument that BACT was "fundamentally unsuited" to GHG regulation because the only way to reduce GHG emissions from a source was

2014); Approval and Promulgation of Air Quality Implementation Plans; Withdrawal of Federal Implementation Plan; Texas; Prevention of Significant Deterioration; Greenhouse Gas Tailoring Rule Revisions, 79 Fed. Reg. 66,641 (Nov. 10, 2014).

${ }^{76}$ Intergovernmental Panel on Climate Change, Climate Change 2013: The Physical Science Basis: Summary for Policymakers 4, 13-14 (2013).

${ }^{77}$ Forrest Wilder, 'Both Sides' Heard at Climate Change Panel, Tex. Observer (Sept. 29, 2013), http://perma.cc/KT24-QQ9G; Neena Satija, Week Reveals Gap Remains Regarding Climate Change, TEX. TRIB. (Oct. 1, 2013), http://perma.cc/8YPC-MHLN.

${ }^{78}$ UARG, 134 S. Ct. 2427 (2014). For a more detailed explanation of the Supreme Court's decision in UARG, see Cecilia Segal, Climate Regulation Under the Clean Air Act in the Wake of Utility Air Regulatory Group v. EPA: Introduction, 39 Harv. EnvtL. L. Rev. 1, 5-6 (2015).

${ }^{79} U A R G, 134$ S. Ct. at 2439.

${ }^{80} \mathrm{Id}$.

${ }^{81} \mathrm{Id}$. at 2445.

${ }^{82} I d$.

${ }^{83} \mathrm{Id}$. at 2447. 
to regulate energy production and use. ${ }^{84}$ Among other things, carbon capture and sequestration was a control technology that should be considered for large GHG emitters. ${ }^{85}$ But certain limitations on BACT ensured that the permit applicant's discretion in imposing energy efficiency requirements was not unbounded. ${ }^{86}$

\section{The Impact of $U A R G$ on GHG Regulation in TeXas}

The Supreme Court's opinion in UARG will probably have very little impact on either the permitting of major sources in Texas or on the tension that still exists between EPA and TCEQ. First, UARG's limitation of the PSD and Title V permitting requirements to BACT determinations for "anyway" sources will have little impact on the number of sources subject to BACT analysis for GHG emissions or on the GHG-emissions reductions that will result. "Anyway" sources account for about eighty-three percent of stationary source GHG emissions in the United States while only about three percent come from sources with GHG emissions that cross the Tailoring Rule's thresholds but with emissions of conventional pollutants that do not cross the statutory 100 and 250 tons per year thresholds ${ }^{87}$ The vast majority of new major sources and existing sources that undergo major modifications in Texas will therefore have to comply with the BACT requirement for GHGs. Thus, as a practical matter, the State of Texas lost its appeal.

Perhaps the most important question going forward concerns the implications of the UARG opinion on the seriousness with which TCEQ will go about the task of implementing the Tailoring Rule. At the insistence of the affected industries, the Texas Legislature enacted legislation authorizing TCEQ to issue permits to sources of GHG emissions, but only "[t]o the extent that greenhouse gas emissions require authorization under federal law." ${ }^{88}$ The Texas Legislature also required TCEQ to repeal the program if "authorization to emit greenhouse gas emissions is no longer required under federal law." ${ }^{99}$ An EPA guidance memo issued a month after the Supreme Court's decision declared that it would no longer require states to include in their SIPs a requirement that non-"anyway" sources obtain PSD permits. ${ }^{90}$ TCEQ will therefore have to amend its regulations to restrict the program to anyway sources. To avoid wasting time approving TCEQ's now defunct GHG program, EPA would be welladvised to wait until TCEQ has complied with the Texas statute.

${ }^{84} \mathrm{Id}$.

${ }^{85} I d$. at 2448.

${ }^{86} \mathrm{Id}$.

${ }^{87}$ Id. at $2438-39$.

${ }^{88}$ Tex. Health and Safety Code $\S 382.05102(b)$ (2013).

${ }^{89} \mathrm{Id}$. $\$ 382.05102(\mathrm{e})$.

${ }^{90}$ Memorandum from Janet G. McCabe, Acting Assistant Adm'r, Office of Air and Radiation, and Cynthia Giles, Assistant Adm'r, Office of Enforcement and Compliance Assurance, to Reg'l Adm'rs 2 (July 24, 2014), http://perma.cc/3PAE-2EFL. 
As noted above, TCEQ's leadership still believes that GHG regulation is wholly unnecessary. Environmental groups have objected to TCEQ's assuming GHG permitting authority because they do not trust TCEQ to make Texas sources toe the line. This concern is magnified by the fact that the Legislature exempted GHG permitting from the formal "contested case" procedures that ordinarily apply to TCEQ permits for individual sources. They also worry that TCEQ's unique three-tiered approach to determining BACT will not require Texas GHG permittees to do enough to reduce GHG emissions. While it remains to be seen whether TCEQ will take its new responsibilities seriously once EPA finally approves its GHG program, that approval is not likely to reduce EPA's workload because it will probably have to respond to many petitions by environmental groups to overturn TCEQ's permitting decisions.

Another question of immediate interest is whether TCEQ's loss in $U A R G$ will dissuade it from playing a similarly obstructionist role in implementing EPA's forthcoming "carbon pollution" regulations governing existing power plants. On June 2, 2014, EPA Administrator McCarthy signed proposed "statespecific rate-based goals for carbon dioxide emissions from the power sector" and "guidelines for states to follow in developing plans to achieve the statespecific goals." ${ }^{11}$ Section 111(d) of the Clean Air Act requires states to submit plans containing performance standards for GHG emissions reflecting the "best system of emission reduction which ... the Administrator determines has been adequately demonstrated" ("BSER"). ${ }^{92}$ Instead of suggesting emission-reduction technologies, however, the Agency proposed "state-specific" GHG emission-reduction goals, which reflected EPA's calculation of the overall "emission limitation that each state can achieve through the application of the BSER" to the relevant sources within the state. ${ }^{93}$

Despite the proposal's great flexibility in meeting its overall goal, the reaction of Texas elected officials suggests that the state will continue its obstructionist ways. The proposal gives the states a great deal of flexibility in meeting the prescribed goals, but also expects the states to cooperate in the spirit of reducing GHG emissions by thirty percent over a ten-year period. ${ }^{94}$ Governor Perry called the proposal "the most direct assault yet" on the Texas energy industry. ${ }^{95}$ Attorney General Greg Abbott, who was at that point a candidate for governor, complained that the Obama Administration was "doubling down on their job-killing agenda with this latest proposal." ${ }^{96}$ And TCEQ continued to

\footnotetext{
${ }^{91}$ Carbon Pollution Emission Guidelines for Existing Stationary Sources: Electric Utility Generating Units, 79 Fed. Reg. 34,830, 34,830 (June 18, 2014).

${ }_{92} I d$. at 34,834 .

${ }^{93} \mathrm{Id}$.

${ }^{94}$ Id. at $34,832-33$.

${ }^{95}$ Tiffany Stecker, EPA Rule Angers Texas, but Will it Hamper Growth?, ClimateWire, June 4, 2014.

${ }^{96}$ Betsy Blaney, Texas Attorney General Plans to Fight New EPA Rule, A.P. Fin. Wire, June 3, 2014.
} 
have "concerns about the EPA's use of the Clean Air Act in lieu of congressional action to regulate $\mathrm{CO}_{2}$ emissions in this manner." ${ }^{97}$

Those statements were made immediately prior to the Supreme Court's opinion in UARG, but there is little reason to believe that the Supreme Court's decision will bring about a shift in Texan attitudes. Indeed, Attorney General Abbott called the holding "a great victory for the rule of law and for the Constitution." ${ }^{88}$ Referring to President Obama's oft-repeated promise to act unilaterally if Congress did not pass GHG legislation, Abbott called the Tailoring Rule "a perfect example of that dangerous philosophy in action." ${ }^{99}$ Since EPA's proposed GHG regulations for existing power plants are another instance of the Executive Branch acting in the face of congressional inaction, it seems likely that the State of Texas will challenge those regulations when they are finalized. The Republican candidate to replace Abbott, State Senator Ken Paxton, was the Tea Party's favorite in the Republican primary. Following the UARG opinion, Paxton wrote that "EPA will continue to flex its muscle when it comes to overbearing regulations," and he "look[ed] forward as the next Attorney General to fighting their power grab and protecting both Texas business and our state's valuable resources." ${ }^{100}$ Both Abbott and Paxton easily won their elections in November. ${ }^{101}$

At the core of the dispute between EPA and TCEQ over GHG regulation is the simple fact that TCEQ's Chairman and the Texas political leadership have still not accepted the propositions that anthropogenic emissions of GHGs are contributing to climate disruption and that climate disruption poses a serious threat to the Texas environment and economy. To the contrary, they insist that imposing GHG emission-reductions requirements on Texas sources will have no discernable effect on the Texas environment, but will have disastrous effects on the Texas economy. We should therefore expect the State of Texas to continue to resist implementation of EPA's GHG regulations and to challenge every new regulation as it has in the past.

\section{Conclusion}

EPA Administrator Gina McCarthy testified in early April 2014 that EPA was working "hand in hand" with TCEQ to speed up the permitting process. ${ }^{102}$

\footnotetext{
${ }^{97}$ Texas Awaits High Court PSD Decision Before Taking Stance on GHG Rule, CLEAN ENERGY ReP., June 22, 2014.

${ }^{98}$ Erica Martinson, Supreme Court Nibbles at EPA's Greenhouse Gas Powers, Politico (June 23, 2014), http://perma.cc/B4PT-VUKL.

${ }^{99} \mathrm{Id}$.

${ }^{100}$ Facebook Post, Sen. Ken Paxton, Breaking News: US Supreme Court Rules Against EPA (June 23, 2014), https://www.facebook.com/senatorkenpaxton/posts/722147171180461.

${ }^{101}$ Michael Brick, Peggy Fikac \& Ericka Mellon, Up and Down the Ballot, a Night of Dominance for GOP in Texas and in Harris County, Hous. CHron. (Nov. 4, 2014), http://perma.cc/M5ZGKEJT.

${ }^{102}$ Tiffany Stecker, McCarthy Uses Budget Hearing to Highlight State-Federal Collaboration, ClimateWire, Apr. 3, 2014.
} 
The change in EPA's attitude toward TCEQ, however, was not necessarily reciprocated. TCEQ Chairman Shaw continued to complain of "fundamental philosophical flaws in EPA's interpretation of the Clean Air Act." ${ }^{103}$ And TCEQ continued to take an industry-friendly approach to its permitting responsibilities. Commissioner Toby Baker commented that "[w]hile it is the responsibility of the industry to understand the rules that govern them, it is just as important for regulators like TCEQ to serve and reach out to the industry." 104

There is an irony in the opposition of Texas politicians to GHG regulation in that strict controls will probably benefit the state economically. ${ }^{105}$ Texas has abundant supplies of natural gas, which yields far fewer pounds of GHG emissions per BTU of energy produced than coal. Texas also has some of the country's best underground repositories for sequestering carbon dioxide. ${ }^{106}$ Indeed, most of the companies with expertise in carbon capture and sequestration reside in Texas. ${ }^{107}$ And Texas leads the nation in wind power production, an alternative to fossil fuels that has historically been more expensive than coal because power producers have been allowed to externalize the costs of climate disruption. ${ }^{108}$ But Texas also leads the nation in coal-fired power production and GHG emissions. ${ }^{109}$ For the time being, at least, Texas regulators will continue to resist the federal government's efforts to address a phenomenon that will probably leave much of their state parched for water as rising sea levels inundate its coastal cities.

\footnotetext{
${ }^{103}$ Examining the Science of EPA Overreach: A Case Study in Texas: Hearing Before the Subcomm. on Science, Space and Technology, 113th Cong. (2014) (testimony of Bryan Shaw, Chairman, TCEQ).

${ }^{104}$ Balancing the Resurgence with Regulation, OIL \& Gas J., Apr. 7, 2014, at 10.

${ }^{105}$ Nathanial Gronewold, Home on the Range-Will it Give Perry a Chance to 'Rethink' Emissions Stance?, ClimateWire, Jan. 24, 2012.

${ }^{106}$ Randy Lee Loftis, Texas is Taking a Greater Interest in Global Warming, Dallas Morning News, Mar. 21, 2009.

${ }^{107} I d$.

${ }^{108} I d$.

${ }^{109}$ Nathanial Gronewold, Electricity-Hungry Texas Discourages Big Coal-Fired Power Plant, CLIMATEWIRE, Feb. 19, 2013.
} 
